\title{
Simulace dopadu revitalizace meandru Jordánu na řece Orlici na režim přilehlého kvartérního kolektoru
}

\section{DAVID ROZMAN, ZBYNĚK HRKAL}

Klíčová slova: revitalizace vodního toku - břehová infiltrace - matematický model - Orlice

\section{SOUHRN}

Velmi urgentní výzvou vodohospodářských organizací v České republice je problematika zadržování vody $\vee$ krajině. Jedna z iniciativ státního podniku Povodí Labe je revitalizace meandru Jordán na toku Orlice. Návrat ríčního toku do původního koryta a technický zásah, který zvýší hladinu do původní úrovně, bude predstavovat významný zásah do vodního režimu. Pozitivní dopad se projeví v prípadě obou klimatických extrémů, povodní i sucha. Bezprostředním dopadem bude zpomalení odtoku povrchové vody, současně se však zvýšení hladiny Orlice projeví v úvodní fázi revitalizace intenzivnější břehovou infiltrací. Výzkumný ústav vodohospodářský T. G. Masaryka, v. v. i., z pověření Ministerstva životního prostředí zahájilo již na konci roku 2018 monitoring režimu podzemních vod $v$ přilehlém kvartérním kolektoru za aktuálního stavu před zahájením revitalizačních opatření. Hladina podzemních vod byla kontinuálně měřena na čtyřech nově realizovaných vrtech. Předkládaná studie představuje výsledky matematického modelu, který simuluje očekávaný dopad technického zásahu na zdroje podzemních vod. Připravené byly simulace současného stavu a stavu po revitalizaci s navýšením hladiny $\vee$ meandru o $1 \mathrm{~m}$ a $\circ 2 \mathrm{~m}$. Podle výsledků modelu bylo spočítané navýšení zásoby podzemních vod v kvartérním kolektoru.

\section{ÚVOD}

Původní koryto řeky Orlice bylo v prostoru Týniště nad Orlicí v minulosti např́imeno. Zrychlení průtoku způsobilo zvýšenou hloubkovou erozi. Zahloubení dna koryta se následně projevilo i na snížení hladiny podzemní vody v přilehlém kvartérním kolektoru.

Nevyhovující současný stav Ize do jisté míry napravit vhodnými úpravami. Revitalizace koryt řek se považuje za vhodný nástroj ke zlepšení nízkých letních průtoků. Lepši akumulace a výměny vody ve vodoteči a v přilehlém nivním kolektoru podzemní vody Ize docílit s pomocí zásahů do koryta. Výzkumníci a vodohospodáři proto propagují revitalizaci řek jako jedno z mitigačních opatření, které zvýší odolnost vodních zdrojů na nepředvídatelné změny stavu vod $\checkmark$ důsledku změny klimatu.

Vyhodnocováním vlivů revitalizací řek se zabývají výzkumníci v tuzemsku [1] i v zahraničí. Studie potvrzují, že revitalizace rek snížila rychlosti odtoku, zvýšila akumulační schopnost (storativitu) nivního kolektoru a navýšila objem základního odtoku [2]. Intenzivnější výměna mezi podzemními a povrchovými vodami skrz sedimenty říčního koryta je zásadní pro chemismus, biogeochemické procesy (okysličenost vody, denitrifikace) a ekologický stav říčního prostředí [3-6]. Zásadním parametrem charakterizujícím komunikaci povrchových a podzemních vod je hydraulická výška řeky [7]. Vliv zařezávání koryta řeky na hladiny podzemní vody v údolní nivě Ize ověřit pomocí numerického modelu [8].

$\checkmark$ rámci současného vodohospodářského trendu, zadržování vody v krajině, získal státní podnik Povodí Labe finanční prostředky na revitalizaci meandru Jordán. Tato aktivita může sloužit jako modelová studie revitalizace celého povodí Orlice až po Hradec Králové. Lokality podobných odškrcených a odstavených meandrů Orlice zmapovala ve své práci například Ležíková [9]. V rámci prací realizovaných v roce 2020 dojde k navrácení toku řeky Orlice do původního koryta a ke zvýšení hladiny v řece spádovým objektem pod meandrem. Cílem studie VúV TGM je modelové posouzení dopadů revitalizace meandru Jordán na hydrogeologické poměry území a na místní zásoby podzemní vody.

\section{METODIKA}

\section{Charakteristika modelového území}

Modelové území s plochou 8,7 km² se nachází v prostoru kvartérních fluviálních sedimentů reky Orlice mezi obcemi Albrechtice nad Orlicí, Týniště nad Orlicí a Petrovice (obr. 1). V jejich podloží se vyskytují jílovce, prachovce a slínovce české křídové pánve.

Na Orlici je dlouhodobě sledován průtok na profilu ČHMÚ u mostu silnice č. 305 mezi Týništěm a Albrechticemi. Podle evidenčního listu profilu činí průměrný roční průtok $18,6 \mathrm{~m}^{3}$, což odpovídá stavu vodoměru $120 \mathrm{~cm}$. Zájmovým územím protéká i levý prítok Orlice Stříbrný potok. U Albrechtic je řeka přehrazena jezem, který slouží k využití vodní energie v malé vodní elektrárně.

Severovýchodně protéká územím vodní náhon Alba, který byl podle historických záznamů vybudován ve 14. století a sloužil k napájení několika rybníků, mlýnů a pil [10]. Průtočná kapacita náhonu je $0,6 \mathrm{~m}^{3} / \mathrm{s}$ a průměrný průtok, stabilní v celé délce je $0,35 \mathrm{~m}^{3} / \mathrm{s}$ [11]. Vodu doplňují př́toky z pravé strany (především Olešnický potok), a naopak k odtokům dochází na levé straně. Povrchová voda v kanálu pravděpodobně komunikuje i s kvartérní zvodní. Souvislost hladiny $v$ kanále s hladinou podzemní vody potvrzuje záznam z archivního vrtu T-1, realizovaného $v$ roce 2001 v těsné blízkosti kanálu. Hladina podzemní vody (HPV) zde dosahovala hloubky 0,75 m pod terénem. 


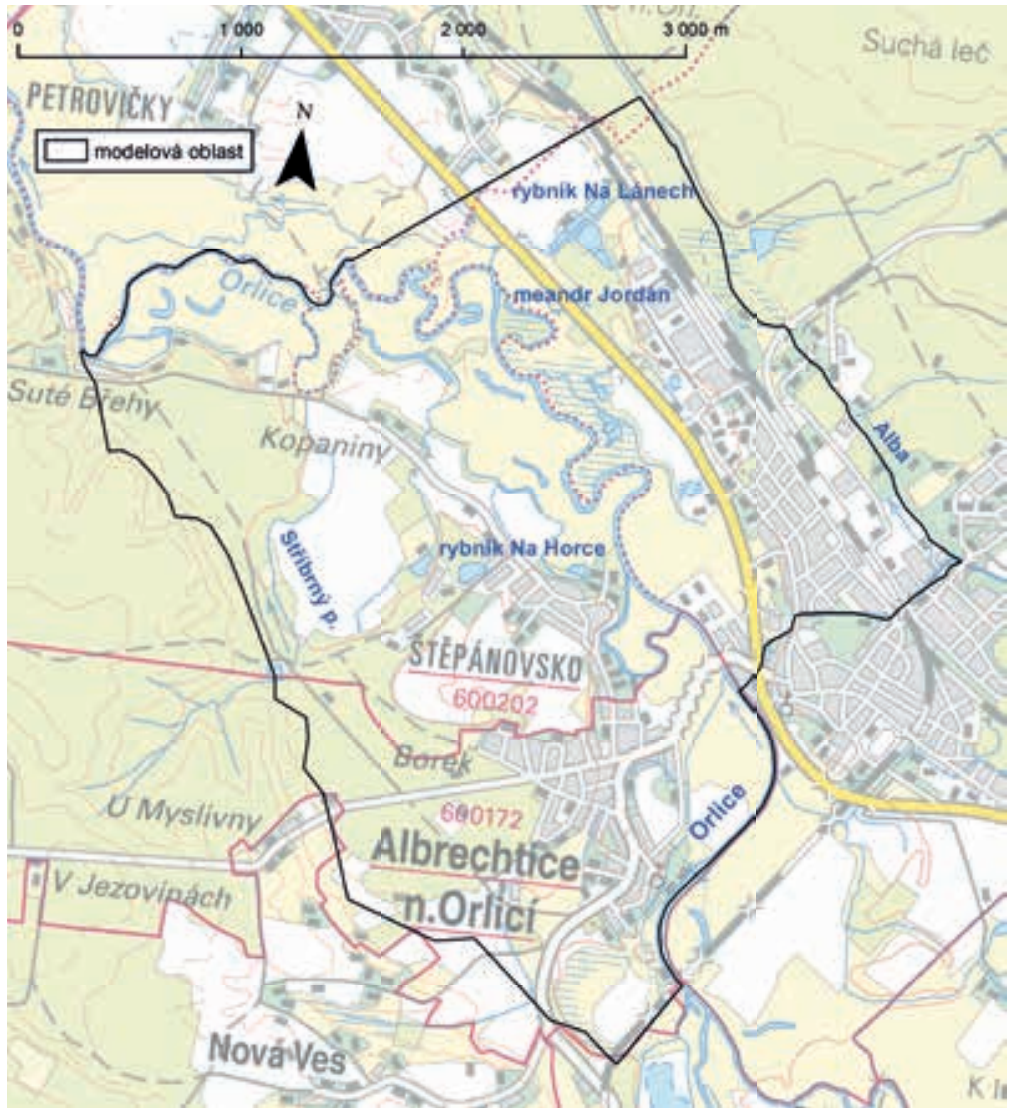

Obr. 1. Mapa modelového území

Fig. 1. Map of the model area

V širší oblasti je odtok regulován sítí mělkých drenážních príkopů. Časté jsou výskyty zamokřených ploch a stojaté vody v odškrcených meandrech. V oblasti je několik malých rybníků (Na Horce u Štěpánovska, Na Lánech mezi silnicí č. 11 a železniční tratí).

Prưměrná roční teplota činí 8-9 ${ }^{\circ} \mathrm{C}$ a průměrný roční srážkový úhrn 600-650 mm. Počet dnů se sněhovou pokrývkou kolísá mezi 50-60 dny a její maximální výška činí 15-20 cm [12].

\section{Geometrie modelu}

Modelové těleso je prostorově definováno z povrchu digitálním modelem terénu (DEM 4G) v rozlišení $10 \times 10 \mathrm{~m}$. Přesnost DEM 4G je na odkryté ploše $30 \mathrm{~cm}$ na zalesněné $100 \mathrm{~cm}$. Bázi modelového tělesa tvoři kontakt kvartérních sedimentů s podložím. Pro jeho vymezení jsme použili soubor 134 archivních vrtů z Geofondu ČR. Ze souboru archivních vrtů byla interpolační metodou Kriging vygenerována plocha podloží kvartérního kolektoru. Do souboru byly priidané i body na okraji prohlubně s nulovou hloubkou kolektoru, které charakterizuji výchozy podložních krídových hornin. Křídové horniny v podloží kvartérních sedimentů predstavují prachovce, slínovce a jílovce s nižší propustností, proto jsou pro účely modelu definované jako nepropustné podloží. Mocnosti modelového tělesa jsou znázorněny na obr. 2.

\section{Gridová sít'}

Výpočetní sít (obr. 3) je definována s rozlišením $25 \times 25 \mathrm{~m}$. V prostoru revitalizace meandru Jordán je sít zahuštěna na rozlišení 6,25 ×6,25 m. Buňky mimo modelovou oblast jsou neaktivní.

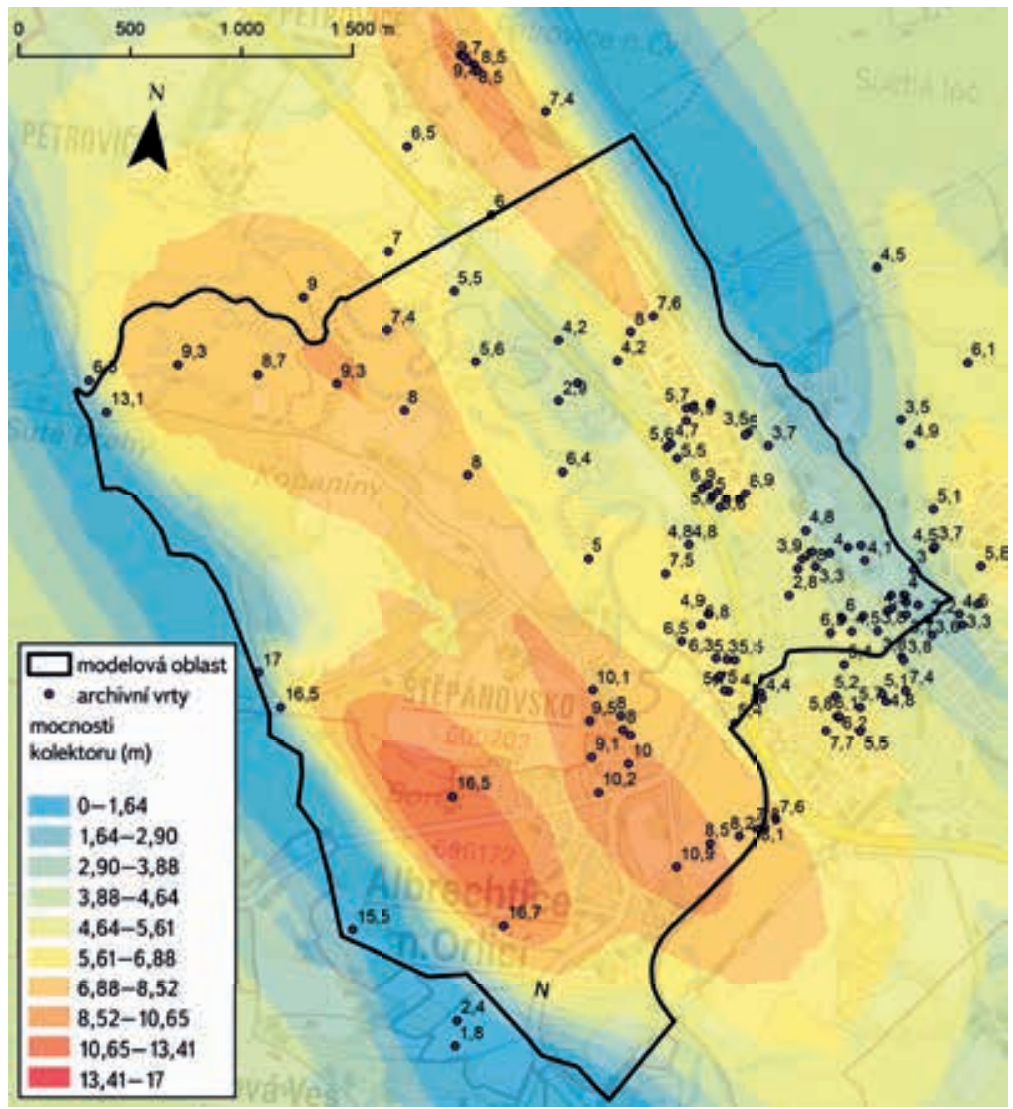

Obr. 2. Situace modelového území se znázorněním mocností kvartérního kolektoru Fig. 2. Situation of model area with representation of quaternary aquifer thickness

\section{Vymezení modelové oblasti a okrajové podmínky}

Modelová oblast je vymezena tak, aby hranice oblasti co nejlépe odpovídaly reálným podmínkám, které určují hydrogeologický režim v oblasti (obr. 3). JZ okraj reprezentuje geologická hranice - výchozy podložních křídových hornin. Zde je v modelu definovaná hranice nulového průtoku (No Flow). SV hranici reprezentuje náhon Alba, kde je v modelu definovaná okrajová podmínka typu řeka (River). Zde v závislosti na hydraulické výšce hladiny ve vodoteči dochází bud'k dotaci, nebo odvodnění podzemní vody. Výšky hladiny byly odhadnuté na základě digitálního modelu terénu mezi 253,5 m n. m. na V a 250,5 m n. m. nas.

SZ hranice je rozdělena na dvě části. První část reprezentuje Orlice, v modelu definovaná jako okrajová podmínka typu řeka (River). Druhá část je spojnice mezi řekou Orlicí a náhonem Alba. Linie spojnice je zhruba kolmá na předpokládaný směr proudění podzemní vody. V modelu je zde definovaná okrajová podmínka typu ustálená hladina (Constant Head).

JV okraj probíhá částečně po vodotečích Orlice a pravém bezejmenném přítoku, který spojuje Albu a Orlici. Tato část je v modelu definovaná okrajovou podmínkou typu řeka. Asi 450 m dlouhý úsek okraje je spojnicí mezi řekou Orlicí a geologickou hranicí s výchozy hornin podloží. Tato linie je v modelu definována jako okrajová podmínka typu ustálená hladina ve výšce odpovídající hladině v Orlici.

Orlice, zásadně určující hydraulické poměry podzemní vody, v modelové oblasti představuje řídící podmínku i v centrální části území. Nejdůležitějším vstupem do modelu jsou zde hydraulické výšky hladiny Orlice opírající se o několik geodeticky zaměřených úrovní hladiny. První opěrný bod je dlouhodobě sledovaný profil ČHMÚ Týniště. Nula vodočtu je zde geodeticky 
zaměřena ve výšce 244,50 m n. m. a průměrný roční stav hladiny je $120 \mathrm{~cm}$ (průtok 18,6 m³/s). Dne 22. 3. 2013 byla geodeticky zaměřena hladina Orlice v místě navrhovaného spádového objektu revitalizovaného meandru Jordán. Výška byla 243,36 m n. m. a tomu odpovídal průtok na profilu Týniště $16,6 \mathrm{~m}^{3} / \mathrm{s}$. Na základě př́čného profilu řeky v místě měření odhadujeme referenční výšku hladiny pro průměrný roční průtok 18,6 m³/s na 243,40 m n. m. Údaje k výpočtu výšky v místě spádového objektu Jordán poskytla společnost Šindlar, s. r. o.

Podle topografických podkladů (Základní mapa ČR 1: 10000 a 1:50 000) byla zmapovaná drenážní sít, pro kterou byla definovaná okrajová podmínka typu drenáž (Drain). Tento typ okrajové podmínky na rozdíl od typu řeka umožňuje pouze odvodnění podzemní vody. Úroveň odvodnění je definována ve výšce $1 \mathrm{~m}$ pod úrovní okolního terénu.

Pro celou plochu modelu je definována okrajová podmínka dotace podzemní vody ze srážek (Recharge). Hodnota dotace byla spočítaná z průměrného srážkového úhrnu 600-650mm [12] a to jako třetinový podíl celkového

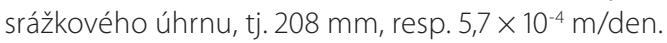

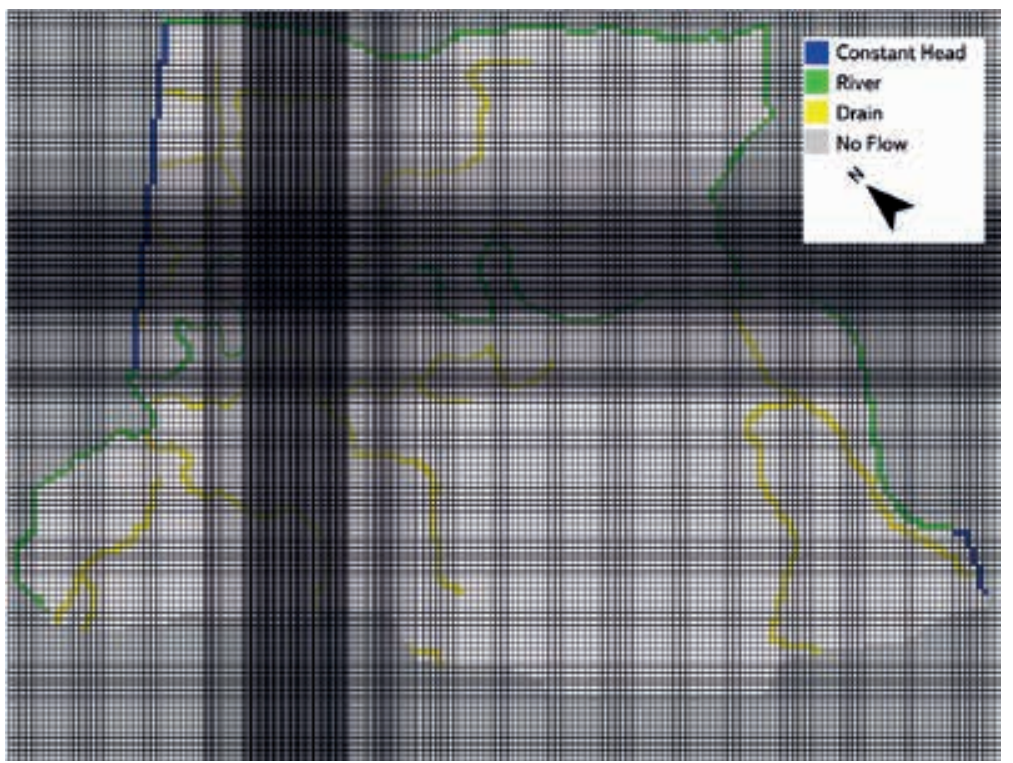

Obr. 3. Gridová sít modelu a okrajové podmínky (Constant Head - konstantní hladina, River - řeka, Drain - drenáž, No Flow - bez průtoku)

Fig. 3. Model grid and boundary conditions

\section{Hydraulická vodivost}

Z archivních vrtů v databázi Geofond byly získané údaje o hydraulické vodivosti (k). V oblasti je k dispozici sedm vrtů s údaji uvedenými v tabulce 1.

Při vyloučení extrémních (max. a min.) hodnot byla jako průměrná hodnota hydraulické vodivosti použita $1,8 \times 10^{-4} \mathrm{~m} / \mathrm{s}$. Hodnoty Kxy a Kz jsou nadále zpřesněné $v$ rámci kalibrace hydraulického modelu.

Tabulka 2. Použité hladiny podzemní vody pro kalibraci modelu Table 2. Groundwater levels used for model calibration

\begin{tabular}{llll} 
Vrt & $\mathbf{X}$ & $\mathbf{Y}$ & $\begin{array}{l}\text { Hladina podzemní } \\
\text { vody [m n. m.] }\end{array}$ \\
\hline AB-2 & -627893 & -1049743 & 242,35 \\
\hline HJ-1-156/5 & -626113 & -1052060 & 248,02 \\
\hline V-1 & -626800 & -1052080 & 250,5 \\
\hline PT-1 & -625923 & -1048386 & 247,2 \\
\hline V-2 & -625477 & -1049228 & 249,66 \\
\hline S-1 & -625600 & -1049510 & 245,35 \\
\hline STUDNA & -626147 & -1050554 & 246,53 \\
\hline ST-1 & -624748 & -1050232 & 251,07 \\
\hline HJ-3 & -624918 & -1049896 & 251,34 \\
\hline HJ-2 & -625025 & -1049845 & 251,01 \\
\hline HJ-4 & -624424 & -1050732 & 251,84 \\
\hline S-2 & -625780 & -1049610 & 245,79 \\
\hline V-129 & -625540 & -1051203 & 246,3 \\
\hline TN-1 & -624825 & -1050570 & 250,43 \\
\hline HV1 & -626298 & -1049381 & 244,42 \\
\hline HV2 & -626309 & -1049551 & 244,36 \\
\hline HV3 & -626113 & -1049242 & 245,81 \\
\hline HV4 & -625994 & -1049337 & 247,26
\end{tabular}

Tabulka 1. Charakteristika použitých vrtů

Table 1. Characteristics of the archive boreholes

\begin{tabular}{|c|c|c|c|c|c|c|}
\hline Vrt & Hloubka & $\mathbf{Y}$ & $x$ & Nadmořská výška [m n. m.] & Rok & $k[\mathrm{~m} / \mathrm{s}]$ \\
\hline HJ-3 & 8 & -1049896 & -624918 & 253,24 & 1990 & 0,0008 \\
\hline$A B-1$ & 17 & -1051480 & -626345 & 252,00 & 1984 & 0,000325 \\
\hline $\mathrm{HJ}-4$ & 8 & -1050732 & -624424 & 253,60 & 1990 & 0,000254 \\
\hline STUDNA & 3,5 & -1050554 & -626147 & 248,53 & 1983 & 0,000201 \\
\hline HJ-2 & 11 & -1049845 & -625025 & 252,88 & 1990 & 0,000075 \\
\hline HJ-1-156/5 & 18,6 & -1052060 & -626113 & 254,00 & 2009 & 0,000062 \\
\hline PT-1 & 20 & -1048386 & -625923 & 251,70 & 1995 & 0,000024 \\
\hline
\end{tabular}




\section{Kalibrace}

Ke kalibraci posloužili údaje o hladině podzemní vody z výběru 14 vrtů z archivu Geofondu a 4 nových průzkumných vrtů v prostoru meandru Jordán (tabulka 2). U použitých vrtů byla úroveň hladiny stanovená z hloubky hladiny a geodeticky zaměřené nadmořské výšky odměrného bodu, případně hodnoty DEM.

Ze čtyř nových vrtů realizovaných VúV TGM za účelem získání informací o režimu podzemní vody $v$ kvartérním kolektoru před revitalizací meandru Jordán, je k dispozici časová řada hladin podzemní vody. Na obr. 4 jsou průběhy hladin srovnané s vodním stavem na profilu ČHMú Týniště nad Orlicí.

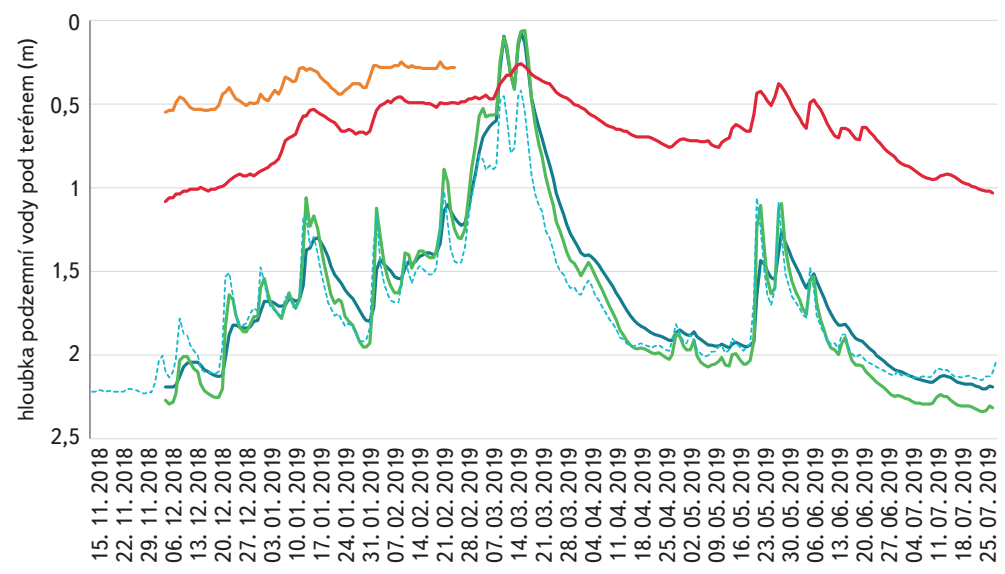

\section{HV1} \begin{tabular}{ll|l|l} 
HV2 & HV3 & HV4 & Orlice stav
\end{tabular}

Obr. 4. Průběhy hladin podzemní vody na monitorovacích vrtech Vúv TGM a v rece Orlici

Fig. 4. Groundwater level on VUV TGM monitoring wells and in Orlice River

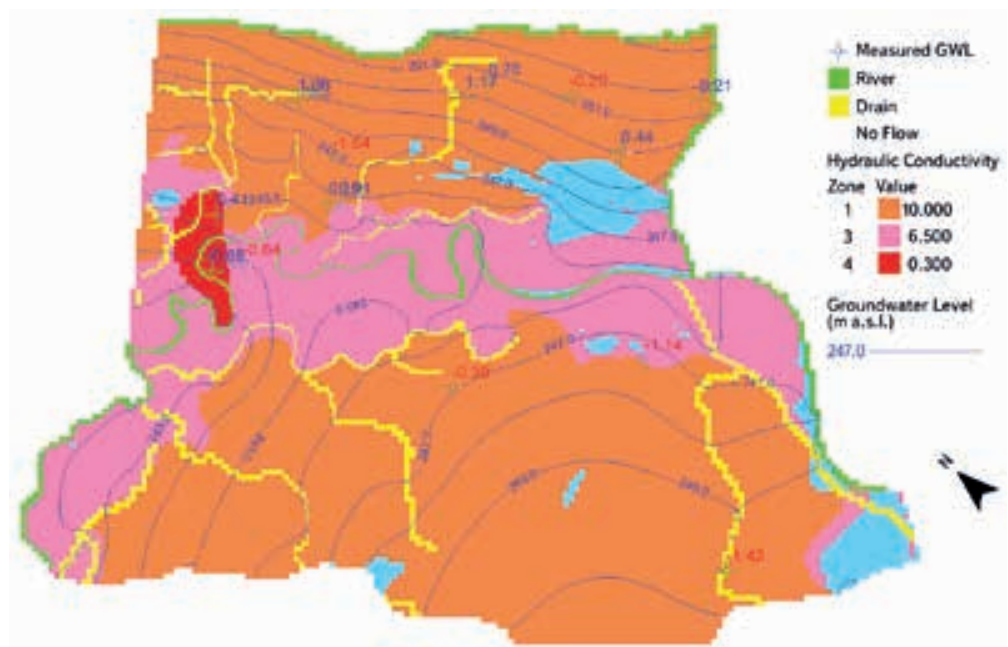

Obr. 5. Simulované hladiny podzemní vody při zavedení plošné heterogenity

hydraulické vodivosti (Measured GWL - změřená HPV, River - řeka, Drain - drenáž, No Flow - bez průtoku, Hydraulic Conductivity - hydraulická vodivost, Value - hodnota, Groundwater level - hladina podzemní vody)

Fig. 5. Resulting groundwater levels for simulation with laterally heterogenic hydraulic conductivity

Pozn.: Modré popisky pozorovacích vrtů znamenají pozitivní odchylky změřených hladin v m, červené negativní, hydraulické vodivosti jsou vyjádřené v jednotkách m/den, modré plochy jsou oblasti zaplavených buněk.
Vrty HV1 a HV2 jsou umístěné v bezprostřední blízkosti koryta Orlice ve vzdálenosti několik desítek metrů uvnitř meandru. Z grafu je proto jasně zřetelné, že hladiny podzemní vody $v$ těchto objektech velmi rychle reagují na změny vodních stavů v řece. Vrty HV3 a HV4 jsou umístěné ve větší vzdálenosti od koryta řeky (100 m, resp. 200 m). I na nich se sice projevuje souvislost s vodním stavem $\checkmark$ řece, nicméně kolísání hladiny podzemní vody již není tak výrazné.

První modelové simulace naznačily, že hydraulická vodivost v modelovém území není homogenní a pro správné fungování modelu byl nutný subjektivní zásah. Při zadání jediné zprůměrované hodnoty hydraulické vodivosti totiž docházelo lokálně k velkým odchylkám mezi měřenými a modelovými hladinami podzemní vody. Proto jsme nejprve hodnoty hydraulické vodivosti snízili v oblasti nejnižší řiční terasy, vymezené na základě topografické mapy a digitálního modelu terénu. V dalším kroku byla hydraulická vodivost snížená i v menší ploše pod meandrem Jordán. Tato varianta (obr.5) se ukázala jako nejlépe odrážející reálné měřené hodnoty hladin podzemní vody.

Nižší propustnost sedimentů nejnižší terasy může být způsobena odlišnými podmínkami sedimentace prí tvorbě jednotlivých terasových stupňů. Oblast nižší propustnosti pod meandrem Jordán Ize vysvětlit lokální změnou facie sedimentace na jemnější frakci. Na popisovanou variabilitu prostředí údolních niv upozorňuje i Krásný a kol. [13]. Možný je ale také vliv přísunu materiálu přítokem ze severovýchodu ze směru od současného rybníku Na Lánech u areálu Elitex.

\section{VÝSLEDKY A DISKUSE}

Stacionární model proudění podzemní vody je zkonstruován na základě dlouhodobých průměrných veličin okrajových podmínek. Výsledky modelu je proto potřeba chápat jako teoretický stav, dosažený po dlouhodobě konstantních podmínkách. Jde o zjednodušenou simulaci prírodních procesů, která nepostihuje vlivy časové proměnlivosti vstupních parametrů.

Podle výsledků modelu se na některých plochách blíži hladina podzemní vody úrovni terénu. Tyto prostory se stávají oblastmi nejistot, protože narážíme na omezení dané nepřesností DEM. Zde bychom pro adekvátní řešení potřebovali pracovat s přesněji zaměřenými terénními daty. Další nejistotu představují nezmapované drenážní prríkopy. Zaplavené plochy, označené na obr. 5, se nachází v místech, kde skutečně dochází k výskytu hladiny podzemní vody $v$ úrovni terénu ve formě menších rybníků, zaslepených meandrů nebo pouze zamokřených ploch:

- mokřina na obou stranách silnice č. 11; mezi prostory Českého svazu chovatelů, místní ČOV a skladovým areálem v ulici Mostecká,

- mokřina východně od silnice č. 305,

— odškrcený meandr u Štěpánovska,

- oblasti rybníků u Stříbrného potoka a západně od Štepánovska,

- oblast u rybníků Na Lánech SZ od areálu Elitex.

Hladina podzemní vody v modelové oblasti je v hloubce do několika metrů pod terénem. Hlouběji zapadlá je ve vyšší terase na severozápadu (Chumlov, nad lokalitou Suté Břehy), kde se hladina nachází v hloubce až 10 m. Poměrně mělká je hladina na pravém břehu Orlice v pásmu podél hlavní silnice č. 11, kde se hladina často nachází v hloubce menší než $1 \mathrm{~m}$. Takovou hloubku dokládají i pozorovací vrty HV3 a HV4. K proudění podzemní vody dochází od okrajů modelové oblasti směrem k toku Orlice, která podzemní vody drénuje. Orlice je skoro $v$ celé oblasti efluentní, influentního charakteru je pouze $v$ úseku nad jezem Albrechtice, kde z důvodu vzduté hladiny dochází k dotaci podzemní vody z řeky. Významná je drenáž do sítě kanálů v celé ploše modelu. K dotaci podzemní vody dochází především plošnou infiltrací ze srážek a z náhonu Alba na severovýchodním okraji modelové oblasti. 


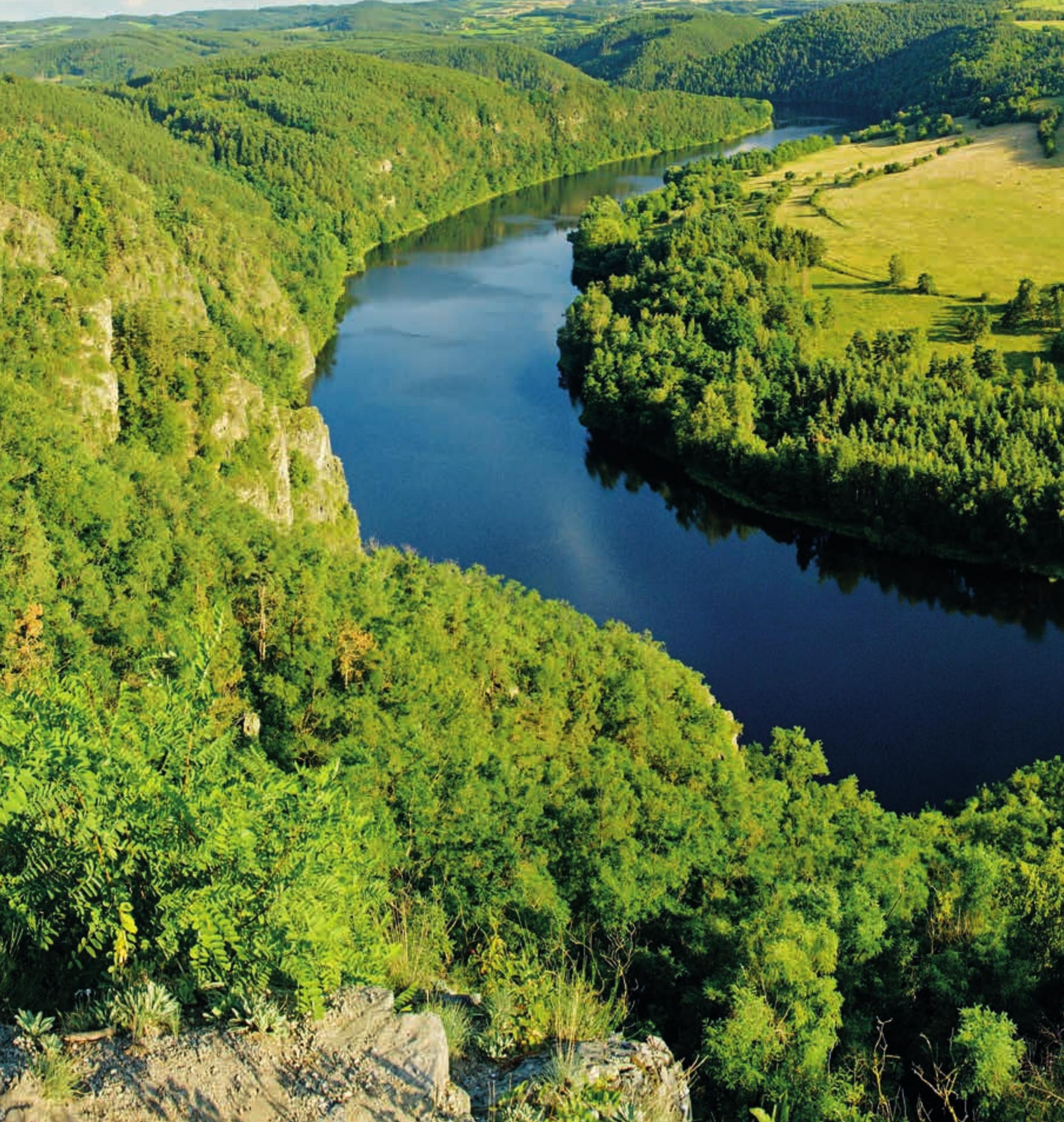




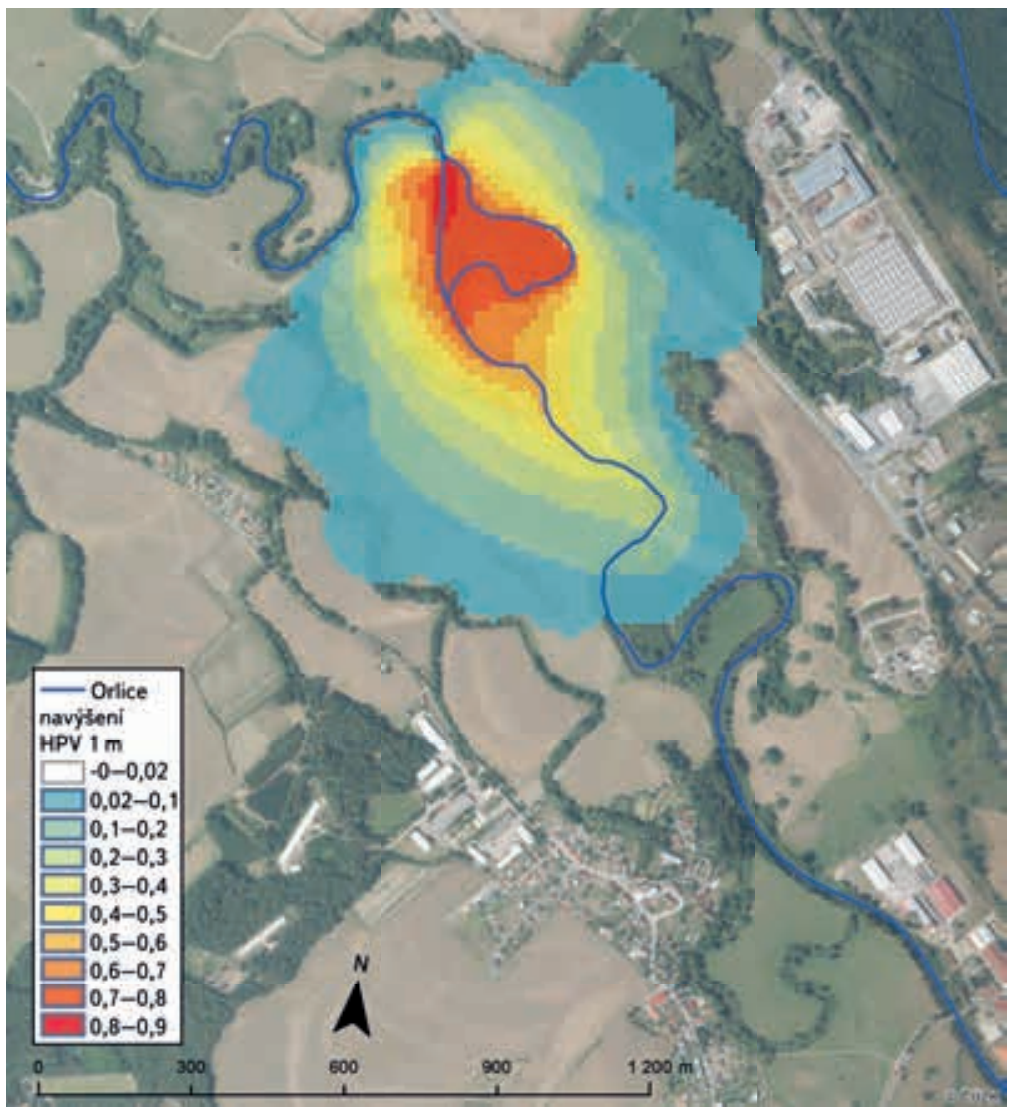

Obr. 6. Simulace dopadu revitalizace meandru s navýšením hladiny o 1 m

Fig. 6. Simulation of meander restoration impact with level increase by $1 \mathrm{~m}$ (navýšení HPV - Groundwater level rise)

Lokální změny hydraulické vodivosti byly interpretované odlišnými parametry pro nejmladši říční terasu a pro menší oblast pod meandrem Jordán.

Pro simulaci revitalizace meandru Jordán byla změněna okrajová podmínka typu řeka v dotčeném úseku. Změněn byl průběh toku Orlice a byla zvýšena hydraulická výška o jeden metr na výšku 244,4 m n. m. pro celý úsek řeky od spádového objektu až do vzdálenosti asi 1600 m proti proudu. Vliv revitalizace zasahuje plochu přesahující 0,75 km², ve které dojde ke zvýšení hladiny podzemní vody v kolektoru (obr. 6).

Simulace plošného zvýšení hladiny podzemní vody umožnila kalkulaci změny zásoby podzemní vody. Pokud zanedbáme navýšení hladiny menší než $1 \mathrm{~cm}$, získáme v prípadě navýšení hladiny v řece o $1 \mathrm{~m}$ hodnotu objemu nově saturovaného horninového prostředí $176760 \mathrm{~m}^{3}$. Za předpokladu že je hodnota efektivní porozity štěrkopískového kvartérního kolektoru okolo 0,2 [14], znamená to tvorbu okolo $35350 \mathrm{~m}^{3}$ nových zdrojů podzemní vody. Pro srovnání, takové množství zhruba odpovídá roční spotřebě vody 1000 obyvatel.

$\checkmark$ prípadě revitalizace $s$ navýšením hladiny $v$ řece o $2 \mathrm{~m}$ se počítá se vzdutím hladiny do vzdálenosti asi 2500 m proti proudu od spádového objektu meandru Jordán. Plocha ovlivnění hladiny podzemní vody je výrazně větší (obr. 7) a podle modelu může dojit i k mírnému zvětšení některých podmáčených ploch u řeky, obzvlášt pak na pravém břehu Orlice mezi ČOV a skladovým areálem v ulici Mostecká. $\vee$ těchto místech model ukazuje navýšení hladiny do $20 \mathrm{~cm}$. Jde zároveň o lokalitu, kde je na leteckých snímcích stále dobře viditelný tvar starého, již zasypaného meandru.

$\checkmark$ prípadě navýšení hladiny v rece o 2 m získáme hodnotu objemu nově saturovaného horninového prostředí $640800 \mathrm{~m}^{3}$. Za stejného předpokladu o efektivní porozitě štěrkopískového kvartérního kolektoru to znamená vytvoření přibližně $128160 \mathrm{~m}^{3}$ nových zdrojů podzemní vody.

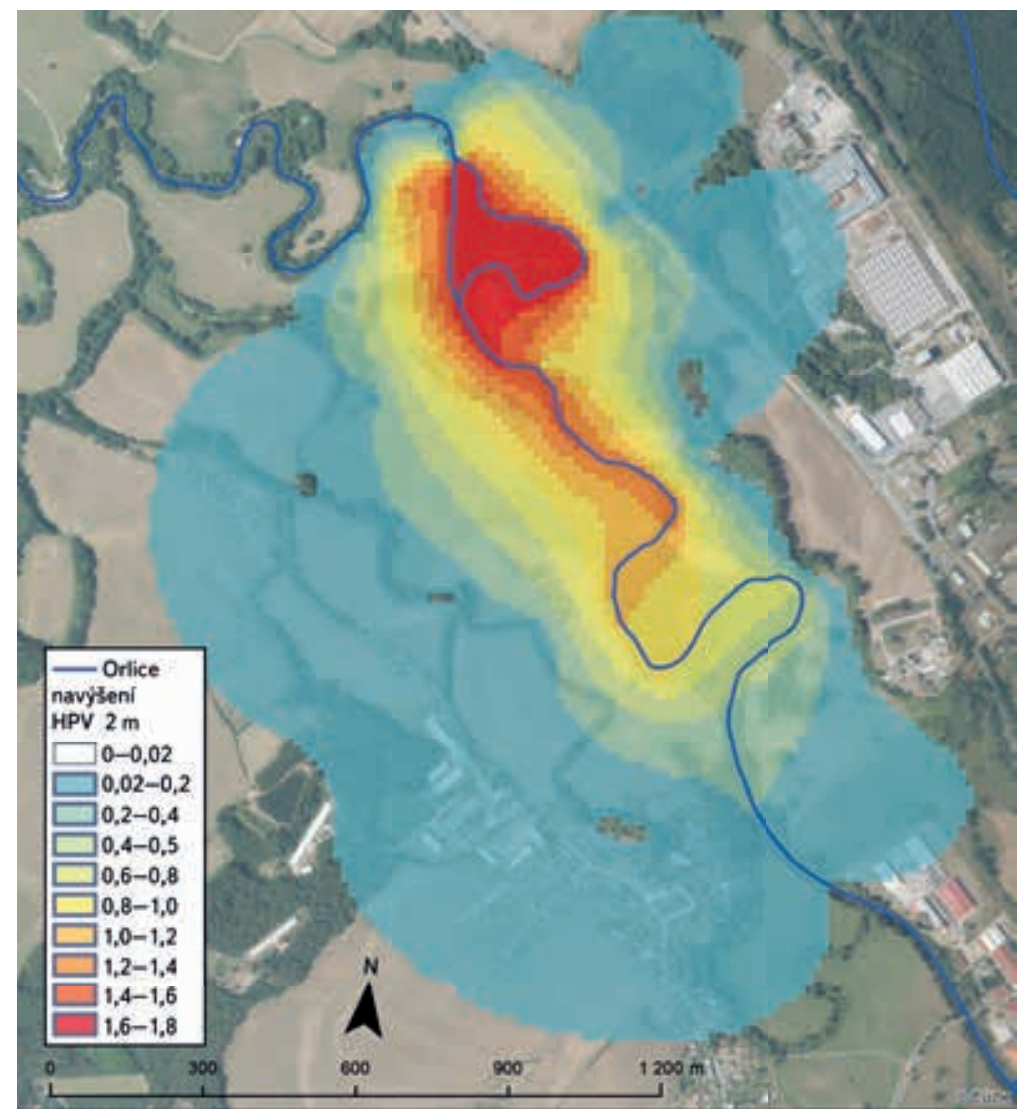

Obr. 7. Simulace dopadu revitalizace meandru s navýšením hladiny o 2 m Fig. 7. Simulation of meander restoration impact with level increase by $2 \mathrm{~m}$ (navýšení HPV - Groundwater level rise)

\section{ZÁVĚR}

Realizace plánované revitalizace meandru Jordánu na toku Orlice u Týniště nad Orlicí bude představovat významný pozitivní zásah do hydrologického i hydrogeologického režimu v okolí. Jednak zpomalí odtok povrchové i podzemní vody, jednak krátce po revitalizaci umožní zintenzivnění břehové infiltrace do přilehlého kvartérního kolektoru. Tato aktivita naplňuje zásady státní politiky boje proti suchu. Spadá do kategorie prírodě blízkých opatření, protože zintenzivňuje původní přírodní procesy, které umožňovaly dlouhodobou retenci vody v krajině. Zvýšení hladiny podzemní vody nepředstavuje žádnou konfliktní aktivitu, protože voda se pouze navrací do svého původního stavu. Modelové simulace například naznačily budoucí podmáčení terénu v oblastech, které $v$ minulosti byly mokřady.

Modelová simulace postavená na ročním monitoringu režimu podzemních a povrchových vod kvantifikovala teoretický nárůst objemu podzemních vod v kvartérních sedimentech o cca 35000 m³ (zvýšení hladiny vodního toku o $1 \mathrm{~m}$ ), resp. cca $128160 \mathrm{~m}^{3}$ (zvýšení hladiny vodního toku o $2 \mathrm{~m}$ ). Tato čísla představují dočasně zadrženou vodu $v$ podobě podzemního odtoku. Využitelné zdroje budou pochopitelně nižší, přesto ale mohou hrát ve vodohospodářsky deficitním královehradeckém kraji dưležitou roli. To především s ohledem na skutečnost, že lokalit vhodných k podobné revitalizaci je na toku Orlice celá raada. Modelová interpolace dat z meandru Jordán na širší území povodí Orlice by byla schopna kvantifikovat vodohospodářský potenciál takovýchto revitalizačních opatření. 


\section{Poděkování}

Studie, na základě které vznikl př́spěvek, byla financovaná interním grantem Výzkumného ústavu vodohospodářského T. G. Masaryka, v. v. i.

\section{Literatura}

[1] JUST, T., ŠÁMAL, V., DUŠEK, M., FISCHER, D., KARLÍK, P. a PYKAL, J. Revitalizace vodního prostředí. Agentury ochrany prírody a krajiny České republiky. Praha, 144 s., 2003.

[2] BRISSETTE, C.M. Stream restoration effects on hydraulic exchange, storage and alluvial aquife discharge. Graduate Student Theses, Dissertations, \& Professional Papers. 10992. Dostupné z: https:// scholarworks.umt.edu/etd/10992, 2017.

[3] KURTH, A.M. WEBER, C. and SCHIRMER, M. How effective is river restoration in re-establishing groundwater-surface water interactions? - A case study. Hydrology and Earth System Sciences. DOI:19. 10.5194/hess-19-2663-2015, 2015.

[4] FINDLAY, S. Importance of surface-subsurface exchange in stream ecosystems: The hyporheic zone. Limnol. Oceanogr., 40, p. 159-164, 1995.

[5] FILOSO, S. and PALMER, M.A. Assessing stream restoration effectiveness at reducing nitrogen export to downstream waters. Ecol. Appl., 21, p. 1989-2006, 2011.

[6] HAASE, P., HERING, D., JÄHNIG, S.C., LORENZ, A.W., and SUNDERMANN, A. The impact of hydromorphologica restoration on river ecological status: a comparison of fish, benthic invertabrates, and macrophytes. Hydrobiologia, 704, p. 475-488, DOI:10.1007/s10750-012-1255-1, 2013.

[7] TRAUTH, N., SCHMIDT, C., VIEWEG, M., OSWALD, S.E., and FLECKENSTEIIN, J.H. Hydraulic controls of in-stream gravel bar hyporheic exchange and reactions. Water Resour. Res., 51, p. 2243-2263, DOI:10.1002/2014WR015857, 2015.

[8] LOHEIDE, S.P., GORELICK, S.M. Riparian hydroecology: A coupled model of the observed interactions between groundwater flow and meadow vegetation patterning. Water Resour. Res., 43, W07414, DOI:10.1029/2006WR005233, 2007

[9] LEŽIKOVÁ, K. Diplomová práce - Současný stav lokalit odškrcených a odstavených meandrů Orlice. Masaryková Univerzita, Prírodovědecká fakulta, Geografický ústav, [online]. [cit. 2019-7-1], 83 str., 2011.

[10] HAKENOVÁ, M. Diplomová práce - Historické změny spojené Orlice za posledních 200 let a hodnocení současného stavu vodního toku. Univerzita Palackého v Olomouci, Prírodovědecká fakulta, Katedra geografie, [online]. [cit. 2019-7-1], 32 str., 2011.

[11] Povodí Labe Povodí Labe - Vodohospodářská bilance za rok 2007. [online]. [cit. 2019-7-1], 7 str.

[12] TOLASZ, R. Atlas podnebí Česka. Praha: Český hydrometeorologický ústav, Olomouc: Univerzita Palackého v Olomouci, 255 str., 2007.

[13] KRÁSNÝ, J., CíSLEROVÁ, M., ČURDA, S. a kol. Podzemní vody České republiky. Praha: Česká geologická služba, 1144 str., 2012.

[14] STŘEMCHA, J., KAHUDA, D., HOSNÉDL, P., PRINZ, J. a ŠEPS, M. Sanace těkavých chlorovaných uhlovodíků v podzemní vodě v predpolí prameniště Bzenec. Aktualizace analýzy rizika 2005. Roční zpráva 2005. SAKOL, Praha, 76 str., 2006.

\section{Autoři}

Mgr. David Rozman ${ }^{1,2}$

凶david.rozman@vuv.cz

ORCID: 0000-0001-9509-3227

doc. RNDr. Zbyněk Hrkal, CSc. ${ }^{1,2}$

凶zbynek.hrkal@vuv.cz

ORCID: 0000-0002-8492-394X

'Výzkumný ústav vodohospodářský T. G. Masaryka, v. v. i.

${ }^{2}$ Prírodovědecká fakulta, Univerzita Karlova

Příspěvek prošel lektorským řízením.
SIMULATION OF THE RESTORATION

OF THE MEANDER JORDAN OF THE ORLICE RIVER AND ITS IMPACT ON THE ADJACENT QUATERNARY AQUIFER

\section{ROZMAN, D., ${ }^{12}$; HRKAL, Z. ${ }^{1,2}$}

'TGM Water Research Institute, p.r.i.

${ }^{2}$ Faculty of Science, Charles University

Keywords: river restoration - bank filtration - numerical model - Orlice

An urgent issue of the water management institutions in the Czech Republic is enhancement of the water retention in the environment. One of the solutions presented by Elbe river basin authority is restoration of the meander Jordan of the Orlice River. Reactivation of the original channel and a technical solution, which will raise the water level to its original height, will have a significant impact on the local hydrological situation. The restoration will mitigate climatic extremes like floods and droughts. A direct impact will be slower surface water runoff and due to higher water level less intense drainage of the groundwater to the river. T. G. Masaryk Water Research Institute started with monitoring of the adjacent Quaternary aquifer at the end of year 2018. The achieved data characterize the situation before the planned restoration. Groundwater level is continually measured in four new monitoring boreholes. This study presents results of a numeric model, which simulates the expected effect of the restoration on the groundwater resources. The simulations include current situation before the restoration, situation after restoration with $1 \mathrm{~m}$ raise in water level and situation after restoration with $2 \mathrm{~m}$ raise in water level. The results also enabled quantification of the potential groundwater storage increase.

DOI: 10.46555/VTEI.2020.01.001 